\title{
Characterization of the Genetic Resources of Farmed Tambaqui in Northern Brazil
}

\author{
Paola F. Fazzi-Gomes ${ }^{1,3}$, Nuno F. Melo ${ }^{1}$, Glauber Palheta ${ }^{1}$, Jonas Aguiar ${ }^{2}$, Iracilda Sampaio ${ }^{2}$, Sidney Santos ${ }^{3}$, \\ Fabiano Moreira ${ }^{3}$, Ândrea K. Ribeiro-dos-Santos ${ }^{3} \&$ Igor Hamoy $^{1}$ \\ ${ }^{1}$ Laboratory of Applied Genetics, University Federal Rural of Amazon, Belém, Brazil \\ ${ }^{2}$ Laboratory of Genetics and Molecular Biology, University Federal do Pará, Bragança, Brazil \\ ${ }^{3}$ Laboratory of Human and Medical Genetics, University Federal do Pará, Belém, Brazil \\ Correspondence: Igor Hamoy, Laboratory of Applied Genetics, University Federal Rural of Amazon Belém, PA \\ 66077830, Brazil. Tel: 55-91-98162-9243. E-mail: igor.hamoy@ufra.edu.br
}

Received: June 25, 2017

doi:10.5539/jas.v9n10p76
Accepted: July 29, 2017 Online Published: September 15, 2017

URL: https://doi.org/10.5539/jas.v9n10p76

\begin{abstract}
The present study analyzed the genetic variability and structure of farmed tambaqui in the Brazilian state of Pará, and provided basic information that can be used for the development of programs of monitoring and management of genetic resources in the aquaculture operations of northern Brazil. A total of 216 individuals were sampled from tambaqui farms in Pará. Genotyping was based on a multiplex set of 10 tri- and tetra-nucleotide microsatellite markers. The data were used to calculate genetic diversity indices, expected and observed heterozygosity, the number of alleles per locus, allelic richness, and inbreeding coefficient. Genetic structure was verified using $\mathrm{D}_{\mathrm{EST}}$ and $\mathrm{R}_{\mathrm{ST}}$, the genetic signature, and Bayesian analysis. The results showed that the tambaqui farms surveyed have suffered a significant loss of genetic variability, and that they are genetically structured, forming two clusters, one encompassing the farms in western Pará, and the other including the farms from the northeast and southeast regions of the state. These finding provide fundamental insights for the development of effective strategies that will help guarantee productivity and the quality of the tambaqui farms of northern Brazil, and provide a database for the upgrading of the genetic variability of these populations. This study indicated the need for hatcheries in southeastern and northeastern Pará to amplify or renew their breeding stocks, in order to avoid the significant loss of genetic diversity in the tambaqui farms of these regions.
\end{abstract}

Keywords: Amazon, Colossoma macropomum, fish, genetic variability, genetic structuring, short tandem repeat

\section{Introduction}

The tambaqui, Colossoma macropomum, is the second most farmed fish species in Brazil, contributing $28.1 \%$ of the country's total production of fish in 2015 . The 135,860 tons produced in this year represent a slight decline, of $2.7 \%$, in comparison with 2014 . The majority $(78.6 \%)$ of this tonnage is produced in northern Brazil, primarily in the state of Rondônia, which accounts for $47.7 \%$ of the national output, and $60.7 \%$ of the tambaqui produced in the northern region of Brazil (IBGE, 2015).

The analysis of the genetic variability of farmed populations, based on molecular markers, has been used successfully to increase the productivity of some fish species by providing systematic guidelines for programs of breeding management and genetic enhancement (Liu \& Cordes, 2004). A reduction in the genetic variability of farmed tambaqui has been recorded in a number of studies, although none have used tri- and tetra-nucleotides, which have the advantage of producing fewer shadow or stutter bands during amplification in comparison with di-nucleotide microsatellite repeats (Munyard et al., 2009).

Given the economic importance of tambaqui farming, and the ongoing loss of genetic variability in captive populations, which may result in reduced productivity, more research is clearly needed. The present study analyzed the levels of genetic variability and structuring in tambaqui farms in the Brazilian state of Pará, providing basic data that can be used for the development of systematic program for the monitoring of genetic resources and the enhancement of the populations held by aquaculture operations in northern Brazil. 


\section{Methods}

\subsection{Ethics Statement}

This project was submitted to the Ethics Committee on the Use of Animals (CEUA) of the Federal Rural University of Amazonia (UFRA). The project was approved and authorized through protocol number 031/2013 (CEUA)-23084.008077/2013-73.

\subsection{Sample Collection}

We collected two small fragments of the caudal fin of 216 fish from farms in the municipalities of Bragança $(\mathrm{n}=$ 25), Capanema $(\mathrm{n}=18)$, Peixe Boi $(\mathrm{n}=18)$, Tracuateua $(\mathrm{n}=18)$, Santarém $(\mathrm{n}=16)$, Itaituba $(\mathrm{n}=18)$, Monte Alegre $(\mathrm{n}=21)$, Óbidos $(\mathrm{n}=28)$, Oriximiná $(\mathrm{n}=26)$, and Conceição do Araguaia $(\mathrm{n}=28)$ (Figure 1). These municipalities belong to three different aquaculture regions of the Amazon Basin — Northeast Pará (Bragança, Capanema, Peixe Boi and Tracuateua), West Pará (Santarém, Itaituba, Monte Alegre, Óbidos and Oriximiná) and Southeast Pará (Conceição do Araguaia).

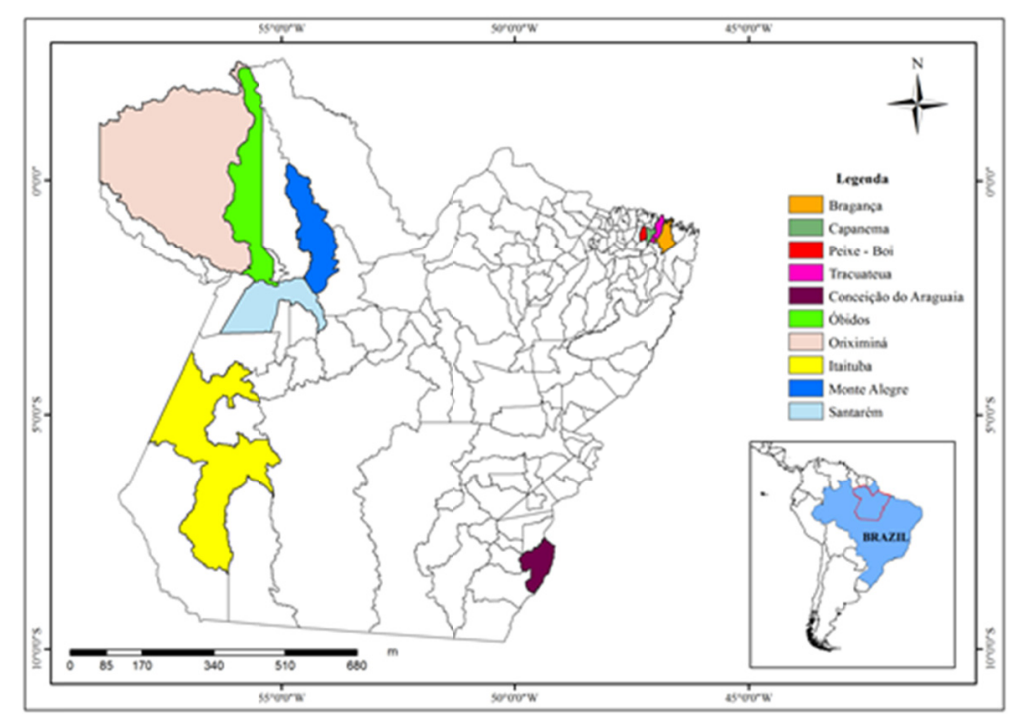

Figure 2. Location of the municipalities in the Brazilian state of Pará where samples of tambaqui were collected from local fish farms

\subsection{DNA Extraction and Quantification}

The DNA was extracted using the Genomic DNA Isolation Kit from the Norgen Biotek Corporation. The concentration of the DNA samples was calculated using the absorbance ratio (A) of the bases at $260 \mathrm{~nm}$ in a NanoDrop $^{\mathrm{TM}}$ ND-1000 spectrophotometer (Thermo Scientific). After quantification, the samples were standardized to a concentration of $5 \mathrm{ng} / \mathrm{uL}$.

\subsection{Genotyping of the Microsatellites}

The samples were genotyped using the multiplex system for 10 microsatellite markers developed by Hamoy and Santos (2012). The PCRs were standardized to a final volume of $8 \mu \mathrm{L}$ containing $6.5 \mu \mathrm{L} 2 \mathrm{X}$ QIAGEN ${ }^{\circ}$ Multiplex PCR Master Mix (Qiagen), $0.5 \mu \mathrm{L}$ of the primers, and $1.0 \mu \mathrm{L}$ of DNA. The samples were amplified in a Veriti thermocycler (Applied Biosystems), based on the following protocol: initial denaturation at $95^{\circ} \mathrm{C}$ for 15 min, followed by 10 cycles of $94{ }^{\circ} \mathrm{C}$ for $30 \mathrm{sec}, 60^{\circ} \mathrm{C}$ for $90 \mathrm{sec}$, and $72{ }^{\circ} \mathrm{C}$ for $60 \mathrm{sec}$, with a final extension at $72{ }^{\circ} \mathrm{C}$ for $60 \mathrm{~min}$.

The PCR products $(1 \mu \mathrm{L})$ were mixed with $8.5 \mu \mathrm{L}$ of Hi-Di deionized formamide (Applied Biosystems) and 0.5 $\mu \mathrm{L}$ of 500 LIZ Gene Scan (Applied Biosystems) for viewing in an Applied Biosystems 3130 automatic capillary sequencer. The individuals were genotyped in the Gene Mapper 3.7 program (Applied Biosystems). Micro-Checker 2.2.3 was used to determine possible genotyping errors and the presence of null alleles. 


\subsection{Estimates of Genetic Diversity}

The observed $\left(\mathrm{H}_{\mathrm{O}}\right)$ and expected $\left(\mathrm{H}_{\mathrm{E}}\right)$ heterozygosity and possible deviations from Hardy-Weinberg equilibrium (HWE) were calculated in Arlequin 3.5.1.3. The p-values were determined following the Bonferroni correction (Rice, 1989).

The number of alleles per locus $\left(\mathrm{N}_{\mathrm{A}}\right)$, allelic richness $\left(\mathrm{A}_{\mathrm{R}}\right)$, and the inbreeding coefficient $\left(\mathrm{F}_{I S}\right)$ per locus were estimated in Fstat 2.9.3.2. The Polymorphic Information Content (PIC) was calculated in Cervus 3.0.

The nonparametric Wilcoxon test with the Bonferroni correction (Rice, 1989) was used to verify the significance of the differences found between the results of the present study and the data available in the literature for wild populations of tambaqui. These analyses were run in the R environment (www.r-project.org).

\subsection{Genetic Structure}

The genetic differentiation between tambaqui farms was assessed using the $\mathrm{R}_{\mathrm{ST}}$ statistic (Slatkin, 1995), run in Arlequin 3.5.1.3, and $\mathrm{D}_{\mathrm{EST}}$ (Jost, 2008), run in the DEMEtics 0.8.7 package of the $\mathrm{R}$ environment (www.r-project.org). A test of genetic attribution was run in GenAlex 6.5 to verify the classification of each individual in either its tambaqui farms of origin or some other tambaqui farm. For this analysis, the populations were grouped in three aquaculture regions, Northeast, West, and Southeast Pará.

To infer the number of genetically homogenous populations $(K)$ that are most likely to exist in the study area, a database was compiled in Structure 2.2. In this analysis, we used $10^{6}$ simulations with $\mathrm{K}$ ranging from 1 to 10 , and discarded a burn-in of 20,000 simulations. The most likely value of $K$ was determined by the $\Delta K$ method described by Evanno et al. (2005), run in Structure Harvester 0.6.94. The CLUMPP 1.1.2 program was used to align the association coefficients for each cluster and to find the best value of $\mathrm{K}$. The distruct 1.1.2 software was used to present the results.

\section{Results}

A total de 104 alleles were identified in the 10 microsatellite loci of the 216 individuals analyzed. The lowest mean $\mathrm{N}_{\mathrm{A}}$ was recorded at Peixe Boi (4.5), and the highest (7.1) at Monte Alegre (see Appendix 1 for complete proofs). The $\mathrm{N}_{\mathrm{A}}$ values recorded in the present study were significantly lower $(\mathrm{P}<0.005)$ than those recorded in previous studies of wild populations. As for the $N_{A}$, the $A_{R}$ values were lower than those recorded for wild tambaqui populations, ranging from 3.701 at Peixe Boi to 5.129 at Monte Alegre. The $A_{R}$ values varied negligibly among the farm populations (see Appendix 1 for complete proofs).

The mean $\mathrm{H}_{\mathrm{O}}$ of the tambaqui farms varied from 0.444 at Tracuateua to 0.672 at Santarém, while the mean $\mathrm{H}_{\mathrm{E}}$ ranged from 0.663 at Peixe Boi to 0.787 at Monte Alegre (see Appendix 1 for complete proofs). Positive mean $F_{\text {IS }}$ values indicate that all the tambaqui populations are endogamous, with values ranging from 0.032 at Santarém to 0.327 at Tracuateua (see Appendix 1 for complete proofs).

The Micro-Checker analysis found no evidence of the presence of stutter bands or null alleles, and the PIC values for all the markers analyzed in the present study were above 0.5 (see Appendix 1 for complete proofs). Following the Bonferroni correction, significant deviations from HWE $(\mathrm{P}<0.005)$ were recorded at many tambaqui farms, mostly due to a deficiency of heterozygotes (see Appendix 1 for complete proofs).

The $\mathrm{D}_{\mathrm{EST}}$ for the whole data set was $0.214(\mathrm{P}<0.001)$, considered to be a moderate level of differentiation by Jost (2008), with the smallest significant pairwise difference being recorded between Bragança and Capanema (0.034), and the largest (0.370) being found between Oriximiná and Tracuateua (see Appendix 2 for complete proofs). The $\mathrm{R}_{\mathrm{ST}}$ values were broadly consistent with the $\mathrm{D}_{\mathrm{EST}}$ analysis, with the smallest significant pairwise difference being found betweenOriximiná and Santarém (0.05), and the largest $(0.1740)$ between Oriximiná and Tracuateua (see Appendix 2 for complete proofs).

The genetic signature indicated that $92 \%$ of the individuals are exclusive to their home farms in northeastern Pará, with the other $8 \%$ originating from other farms. In western Pará, $81 \%$ of the individuals are exclusive to their farm of origin, while the other $19 \%$ originated from other farms. In southeastern Pará, $71 \%$ are exclusive to their home farms and $29 \%$ were related to other sites. Overall, $83 \%$ of the individuals screened could be traced to their farm of origin, and $17 \%$ to other farms.

The Bayesian analysis indicated the existence of two clusters $(\mathrm{K}=2)$ in our data set, which was corroborated by the CLUPP alignment algorithm, with one cluster formed by the farms of northeastern and southeastern Pará, and the other by those from western Pará (Figure 2). 

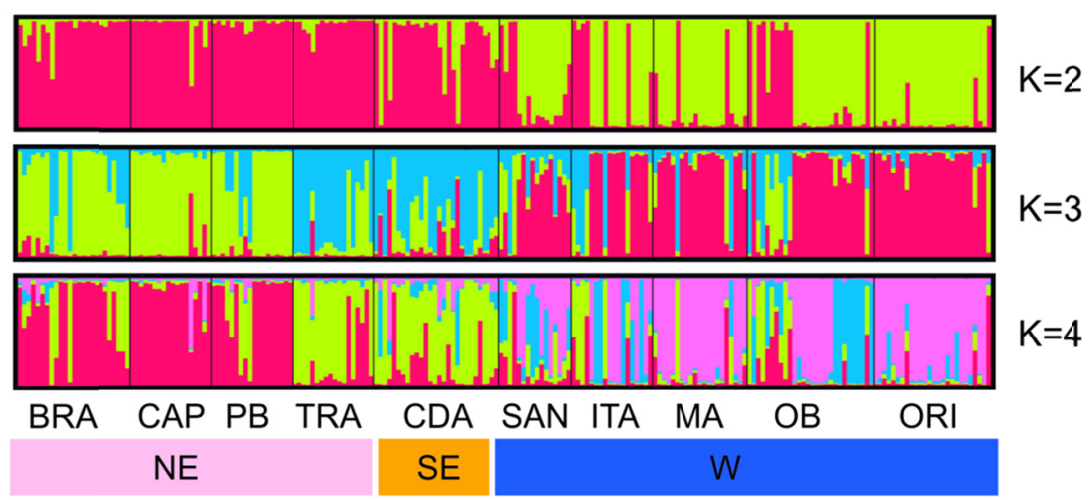

Figure 2. Standard population structure, as determined by STRUCTURE, indicating the existence of two groups $(\mathrm{K}=2)$

\section{Discussion}

The tambaqui is the second most farmed fish in Brazil, and the principal native species raised in the country's aquaculture operations. This emphasizes the need for the systematic investigation of the levels of genetic diversity of farmed populations, given that these data are fundamental to the establishment and development of effective programs of genetic management and enhancement.

In the present study, which surveyed tambaqui farms in three aquaculture regions of the Brazilian state of Pará, a marked reduction in the genetic variability of the populations was found, as shown by the $\mathrm{N}_{A}, \mathrm{H}_{E}$ and $\mathrm{A}_{\mathrm{R}}$ indices (Appendix 1). The $\mathrm{N}_{\mathrm{A}}$ values recorded here were considerably lower than those obtained for wild tambaqui populations, by Hamoy et al. (2011): mean $\mathrm{N}_{\mathrm{A}}=7$; Hamoy and Santos (2012): mean $\mathrm{N}_{\mathrm{A}}=8$.6; Aldea-Guevara et al. (2013): mean $\mathrm{N}_{\mathrm{A}}=8.58$; and Fazzi-Gomes et al. (2017): mean $\mathrm{N}_{\mathrm{A}}=9.13$ (Figure 3).

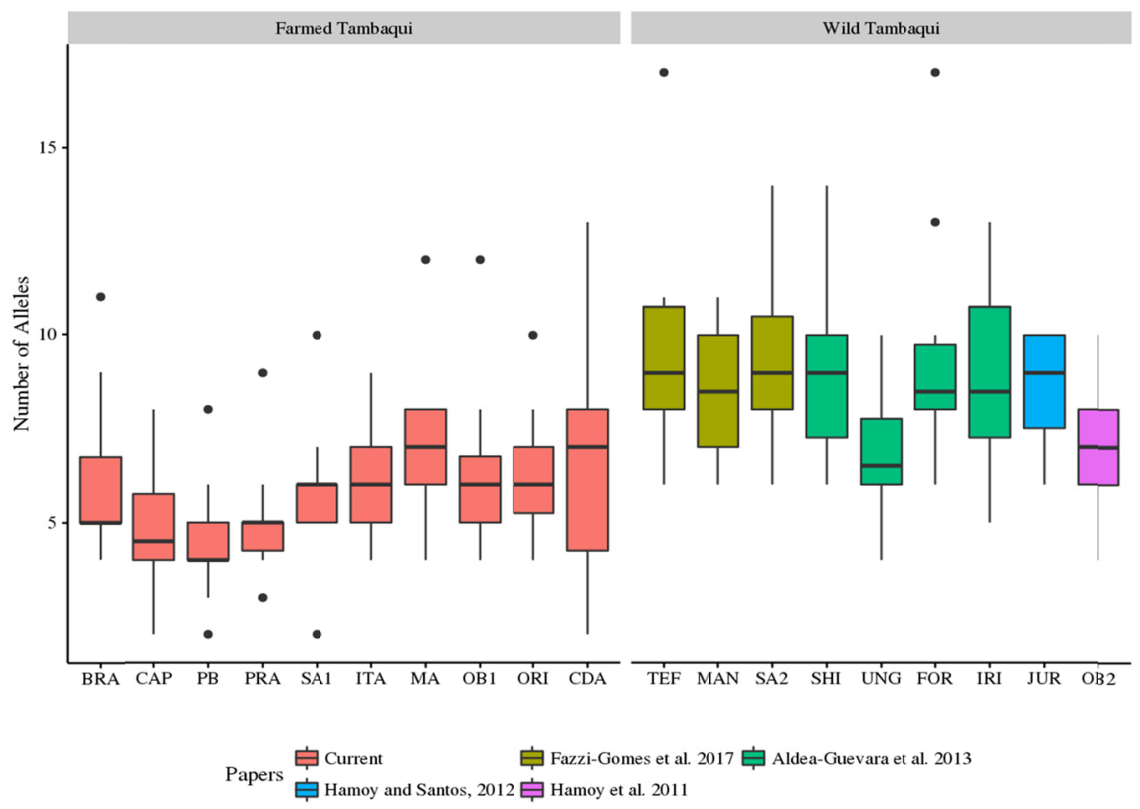

Figure 3. Box plot comparing the number of alleles per locus in the farmed tambaqui (analyzed in the present study) with the genetic variability of wild populations

The mean $\mathrm{H}_{\mathrm{E}}$ of the farmed populations of northeastern and southeastern Pará were also much lower than the values recorded for wild tambaqui populations by Hamoy et al. (2011): mean $\mathrm{H}_{\mathrm{E}}=0.77$; Hamoy and Santos (2012): mean $\mathrm{H}_{\mathrm{E}}=0.79$; Aldea-Guevara et al. (2013): mean $\mathrm{H}_{\mathrm{E}}=0.801$; and Fazzi-Gomes et al. (2017): mean 
$\mathrm{H}_{\mathrm{E}}=0.796$. These differences were expected, given that most farms are based on a small founder population - sometimes even a single pair - with the fry being produced through the mating of closely-related individuals (Santos et al., 2016). Over the long term, this reduced variability may result in decreased resistance to disease (Taniguchi, 2003) and the loss of the capacity to adapt to changes in environmental conditions (Bijlsma \& Loeschcke, 2012).

In western Pará, however, the $\mathrm{H}_{\mathrm{E}}$ values were more similar to those of the wild populations (see above). High $\mathrm{H}_{\mathrm{E}}$ values were recorded by Aguiar et al. (2013) in tambaqui from farms in western Pará, which these authors related to the proximity of the farms to the Amazon River, which enables them to renew their breeding stock from wild populations relatively easily. By contrast, eastern Pará is far from the geographic range of stock from wild populations. The easy access to wild populations for the replenishment of breeding stocks in western Pará presumably contributed to the $\mathrm{H}_{\mathrm{E}}$ values recorded in the present study.

The $A_{R}$ values recorded in the present study reflect a clear loss of genetic variability in all the farmed populations in comparison with the wild tambaqui populations analyzed by Fazzi-Gomes et al. (2017): mean $A_{R}$ $=8.6$. As this parameter is not biased by sample size, it is a relatively reliable index of the loss of genetic variability (Spencer et al., 2000).

The PIC values were considered to be of good quality, and highly informative (Botstein et al., 1980). The principal factor determining deviations from HWE was a deficiency of heterozygotes, a pattern also recorded by Aldea-Guevara et al. (2013) for the same markers. A deficiency of heterozygotes reflects high levels of endogamy in the founding stocks, given that the farms with the largest numbers of markers out of equilibrium (HWE), Tracuateua and Óbidos, also presented the highest $\mathrm{F}_{\text {IS }}$ values. Similarly low levels of genetic variability were recorded in other markers by Santos et al. (2012, 2016), Gomes et al. (2012), and Calcagnotto and Toledo-Filho (2000) in tambaqui farms in a number of different Brazilian regions.

A number of different factors may combine to provoke the loss of genetic diversity found in the tambaqui farms analyzed in the present study. One fundamental factor is the inadequate genetic management of the breeding stock by the local hatcheries, which may have no information on the genetic distance between individuals, resulting in the mating of closely-related fish, and the loss of genetic variability in the descendants. In contrast with other species of economic interest, programs of genetic enhancement are rare in farmed fish, and in fact, the production of interspecific hybrids has been used as a strategy to guarantee a rapid response to captive conditions.

\subsection{Genetic Structure}

In general, both the $\mathrm{R}_{\mathrm{ST}}$ and the $\mathrm{D}_{\mathrm{EST}}$ (Appendix 2) indicated moderate levels of genetic differentiation between the study tambaqui farms. A similar pattern was recorded by Santos et al (2016), with $\mathrm{R}_{\mathrm{ST}}$ values ranging from 0.184 to 0.265 in tambaqui farms in different Brazilian regions. By contrast, Fazzi-Gomes et al. (2017) recorded $\mathrm{F}_{\mathrm{ST}}$ and $\mathrm{R}_{\mathrm{ST}}$ of zero for wild populations. In our study, the values reflect the differentiation of the distinct breeding stocks used to form the study farms.

The genetic structure indicated by the Bayesian analysis indicated that the loss of genetic variability in the tambaqui farms studied here is related to the formation of two clusters $(K=2)$ (Figure 2), supported by the approach of Evanno et al. (2005). One cluster was formed by the farms from northeastern and southeastern Pará, as confirmed by the genetic signature, in particular considering that the farm in southeastern Pará had a high percentage $(29 \%)$ of individuals that originated from other farms. The second cluster is formed by the farms from western Pará. This structuring pattern is the result of the domestication of the tambaqui, given that no such structuring is found in the natural populations of the species (see Fazzi-Gomes et al., 2017).

\section{Conclusions}

A significant loss of genetic variability was found in the tambaqui farms of northeastern and southeastern Pará, in comparison with wild tambaqui populations. The tambaqui farms from western Pará presented much lower levels of loss of genetic variability in comparison with the wild tambaqui populations. The tambaqui farms of these three regions are structured in two main groups.

The findings of the present study represent a major advance for the fish farming operations in the Amazon region and the rest of Brazil. The reliable determination of the genetic diversity and structure of the stocks of the tambaqui farms of the state of Pará, based on accurate molecular markers, such as microsatellites, provides a fundamentally important database for the development of effective programs of genetic management and enhancement. These programs should contribute to the productivity of the farms and the quality of the produce, as well as a reduction in the fishery pressure on the natural stocks of this important Brazilian fish species. 
The findings of this study indicate the need for the amplification or renovation of the breeding stocks of the hatchery in northeastern and southeastern Pará, in order to limit the loss of genetic diversity in the tambaqui farms of these regions.

\section{Acknowledgements}

We thank the funding research agencies CAPES (Rede de Pesquisa em Genômica Populacional Humana/RPGPH (3381/2013 CAPES-BioComp/CAPES); CNPq; FAPESPA (Programa Primeiros Projetos-PPP-FAPESPA/CNPq/ 007/2013) and FADESP/PROPESP/UFPA (Universidade Federal do Pará). ÂNDREA RIBEIRO-DOS-SANTOS supported by CNPq/Produtividade (CNPQ 304413/2015-1); SIDNEY SANTOS supported by CNPq/ Produtividade (CNPq 305258/2013-3). The funders had no role in the study design, data collection and analysis, decision to publish, or preparation of the manuscript.

\section{References}

Aguiar, J., Schneider, H., Gomes, F., Carneiro, J., Santos, S., Rodrigues, L. R., \& Sampaio, I. (2013). Genetic variation in native and farmed populations of Tambaqui (Colossoma macropomum) in the Brazilian Amazon: regional discrepancies in farming systems. Anais da Academia Brasileira Ciências, 8, 1439-1447. https://doi.org/10.1590/0001-376520130007

Aldea-Guevara, M., Hargrove, J., \& Austin, J. D. (2013). Diversity and gene flow in a migratory frugivorous fish: implications for Amazonian habitat connectivity. Conservation Genetics, 14, 935-942. https://doi.org/10.1007/s10592-012-0442-y

Bijlsma, R., \& Loeschcke, V. (2012). Genetic erosion impedes adaptive responses to stressful environments. Evolutionary Applications, 5, 117-129. https://doi.org/10.1111/j.1752-4571.2011.00214.x

Botstein, D., White, R. L., Skolnick, M. H., \& Davies, R. W. (1980). Construction of a genetic linkage map in man using restriction fragment length polymorphisms. The American Journal of Human Genetics, 32, 314-331.

Calcagnotto, D., \& Toledo-Filho, A. S. (2000). Loss of genetic variability at the transferrin locus in five hatchery stocks of tambaqui (Colossoma macropomum). Genetics and Molecular Biology, 23, 127-130. http://dx.doi.org/10.1590/S1415-47572000000100023

Evanno, G., Regnaut, S., \& Goudet, J. (2005). Detecting the number of clusters of individuals using the software STRUCTURE: A simulation study. Molecular Ecology, 14, 2611-2620. https://doi.org/10.1111/j.1365-294X. 2005.02553.x

Fazzi-Gomes, P. F., Guerreiro, S., Palheta, G. D. A., Melo, N. F. A. C., Santos, S., \& Hamoy, I. (2017). High genetic diversity and connectivity in Colossoma macropomum in the Amazon basin revealed by microsatellite markers. Genetics and Molecular Biology, 40, 142-146. https://doi.org/142-146.10.1590/ 1678-4685-GMB-2015-0222

Gomes, F., Schneider, H., Barros, C., Sampaio, D., Hashimoto, D., Porto-Foresti, F., \& Sampaio, I. (2012). Innovative molecular approach to the identification of Colossoma macropomum and its hybrids. Anais da Academia Brasileira de Ciências, 84, 517-525. http://doi.org/10.1590/S0001-37652012005000025

Hamoy, I. G., \& Santos, S. (2012). Multiplex PCR panel of microsatellite markers for the tambaqui, Colossoma macropomum, developed as a tool for use in conservation and broodstock management. Genetics and Molecular Research, 11, 141-146. https://doi.org/10.4238/2012

Hamoy, I. G., Cidade, F. W., Barbosa, M. S., Gonçalves, E. C., \& Santos, S. (2011). Isolation and characterization of tri and tetranucleotide microsatellite markers for the tambaqui (Colossoma macropomum, Serrasalmidae, Characiformes). Conservation Genetics Resources, 3, 33-36. https://doi.org/10.1007/s12686010-9275-5

IBGE (Instituto Brasileiro de Geografia e Estatística). (2015). Produção da Pecuária Municipal. Retrieved from http://biblioteca.ibge.gov.br/visualizacao/periodicos/84/ppm_2015_v43_br.pdf

Jacometo, C. B., Barrero, N. M. L., Rodriguez-Rodriguez, M. D. P., Gomes, P. C., \& Povh, J. A. (2010). Genetic variability of tambaqui (Teleostei: Characidae) from different regions of Brazil. Pesquisa Agropecuária Brasileira, 45, 481-487. http://doi.org/10.1590/S0100-204X2010000500007

Jost, L. (2008). GST and its relatives do not measure differentiation. Molecular Ecology, 17, 4015-4026. https://doi.org/10.1111/j.1365-294X.2008.03887.x 
Liu, Z. J., \& Cordes, J. F. (2004). DNA marker technologies and their applications in aquaculture genetics. Aquaculture, 238, 1-37. https://doi.org/10.1016/j.aquaculture.2004.05.027

Lopes, T. S., Streit Junior, D. P., Ribeiro, R. P., Povh, J. A., Lopera Barrero, N. M., Vargas, L., ... Queiroz, J. R. (2009). Genetic diversity of Colossoma macropomum broodstocks. Arquivo Brasileiro de Medicina Veterinária e Zootecnia, 61, 728-735. http://doi.org/10.1590/S0102-09352009000300029

Moreira, A. A., Hilsdorf, A. W. S., Silva, J. V., \& Souza, V. R. (2007). Genetic variability of two Nile tilapia strains by microsatellites markers. Pesquisa Agropecuária Brasileira, 42, 521-526. http://doi.org/10.1590/ S0100-204X2007000400010

Munyard, K. A., Ledger, J. M., Lee, C. Y., Babra, C., \& Groth, D. M. (2009). Characterization and multiplex genotyping of alpaca tetranucleotide microsatellite markers. Small Ruminant Research, 85, 153-156. https://doi.org/10.1016/j.smallrumres.2009.07.012

Rice, W. R. (1989). Analyzing tables of statistical tests. Evolution, 43, 223-225. https://doi.org/10.2307/2409177

Santos, C. H. A., Leitão, M. A. B., Sousa, C. F. S., Santana, G. X., Silva, M. N. P., \& Almeida-Val, V. M. F. (2012). Genetic variability of wild and captivity populations of Colossoma macropomum (Cuvier, 1818). Acta Scientiarum. Biological Sciences, 34, 191-197. http://doi.org/10.4025/actascibiolsci.v34i2.7149

Santos, C. H. A., Santana, G. X., Leitão, C. S. S., Paula-Silva, M. N., \& Almeida-Val, V. M. F. (2016). Loss of genetic diversity in farmed populations of Colossoma macropomum estimated by microsatellites. Animal Genetics, 47, 373-376. https://doi.org/10.1111/age.12422

Slatkin, M. A. (1995). Measure of population subdivision based on microsatellite allele frequency. Genetics, 139 , 457-462.

Spencer, C. C., Neigel, J. E., \& Leberg, P. L. (2000). Experimental evaluation of the use fullness of microsatellite DNA for detecting demographic bottlenecks. Molecular Ecology, 9, 1517-1528. https://doi.org/10.1046/ j.1365-294x.2000.01031.x

Taniguchi, N. (2003). Genetic factors in brood stock management for seed production. Reviews in Fish Biology and Fisheries, 13, 175-185. https://doi.org/10.1023/B:RFBF.0000019479.49749.fe

\section{Appendix}

Appendix 1. Genetic diversity indices for the farmed tambaqui analysed in the present study $(\mathrm{N}=216)$ based on 10 microsatellite DNA markers. Number of alleles per locus $\left(\mathrm{N}_{\mathrm{A}}\right)$, allelic richness $\left(\mathrm{A}_{\mathrm{R}}\right)$, observed $\left(\mathrm{H}_{\mathrm{O}}\right)$ and expected $\left(\mathrm{H}_{\mathrm{E}}\right)$ heterozygosity, inbreeding coefficient $\left(\mathrm{F}_{\mathrm{IS}}\right)$ per locus and polymorphic information content (PIC)

\begin{tabular}{|c|c|c|c|c|c|c|c|c|c|c|c|}
\hline Locus & & $\begin{array}{l}\text { BRA } \\
(n=25)\end{array}$ & $\begin{array}{l}\text { CAP } \\
(n=18)\end{array}$ & $\begin{array}{l}\text { PB } \\
(n=18)\end{array}$ & $\begin{array}{l}\text { TRA } \\
(n=18)\end{array}$ & $\begin{array}{l}\text { CDA } \\
(n=28)\end{array}$ & $\begin{array}{l}\text { STM } \\
(n=16)\end{array}$ & $\begin{array}{l}\text { ITA } \\
(n=18)\end{array}$ & $\begin{array}{l}\text { MA } \\
(n=21)\end{array}$ & $\begin{array}{l}\text { OB } \\
(n=28)\end{array}$ & $\begin{array}{l}\text { ORI } \\
(n=27)\end{array}$ \\
\hline \multirow[t]{7}{*}{ Cmacr $\mu 01$} & $\mathbf{N}_{\mathbf{A}}$ & 5 & 2 & 4 & 3 & 2 & 5 & 4 & 4 & 5 & 4 \\
\hline & $\mathbf{A}_{\mathrm{R}}$ & 3.048 & 1.986 & 2.665 & 2.221 & 1.731 & 3.732 & 3.173 & 3.285 & 3.980 & 3.501 \\
\hline & $\mathbf{H}_{\mathbf{O}}$ & 0.720 & 0.388 & 0.777 & 0.222 & 0.185 & 0.867 & 0.412 & 0.632 & 0.750 & 0.560 \\
\hline & $\mathbf{H}_{\mathbf{E}}$ & 0.586 & 0.386 & 0.528 & 0.294 & 0.171 & 0.671 & 0.447 & 0.667 & 0.682 & 0.662 \\
\hline & $\mathbf{P}_{\mathrm{HW}}$ & 0.1250 & 1 & 0.0669 & 0.3894 & 1 & 0.2960 & 0.2503 & 0.2891 & 0.7823 & 0.3519 \\
\hline & $\mathbf{F}_{\text {IS }}$ & -0.234 & -0.008 & -0.492 & 0.249 & -0.083 & -0.305 & 0.082 & 0.055 & -0.101 & 0.157 \\
\hline & PIC & 0.495 & 0.305 & 0.429 & 0.258 & 0.154 & 0.594 & 0.407 & 0.585 & 0.627 & 0.593 \\
\hline \multirow[t]{7}{*}{ Cmacr $\mu 03$} & $\mathbf{N}_{\mathrm{A}}$ & 9 & 7 & 5 & 5 & 8 & 5 & 7 & 8 & 6 & 6 \\
\hline & $\mathbf{A}_{\mathrm{R}}$ & 5.189 & 5.294 & 3.967 & 3.868 & 4.216 & 3.756 & 4.728 & 5.064 & 3.837 & 4.510 \\
\hline & $\mathbf{H}_{\mathbf{O}}$ & 0.640 & 0.833 & 0.722 & 0.111 & 0.625 & 0.437 & 0.647 & 0.722 & 0.642 & 0.654 \\
\hline & $\mathbf{H}_{\mathrm{E}}$ & 0.778 & 0.801 & 0.686 & 0.695 & 0.692 & 0.645 & 0.756 & 0.759 & 0.670 & 0.737 \\
\hline & $\mathbf{P}_{\mathrm{HW}}$ & 0.0080 & 0.0791 & 0.1887 & 0 & 0.0389 & 0.1513 & 0.1669 & 0.6052 & 0.0388 & 0.1831 \\
\hline & $\mathbf{F}_{\text {IS }}$ & 0.181 & -0.041 & -0.055 & 0.919 & 0.099 & 0.329 & 0.14 & 0.049 & 0.041 & 0.116 \\
\hline & PIC & 0.73 & 0.748 & 0.621 & 0.618 & 0.628 & 0.570 & 0.695 & 0.701 & 0.608 & 0.680 \\
\hline \multirow[t]{2}{*}{ Cmacro04 } & $\mathbf{N}_{\mathrm{A}}$ & 7 & 6 & 6 & 5 & 4 & 6 & 5 & 6 & 7 & 7 \\
\hline & $\mathbf{A}_{\mathbf{R}}$ & 4.815 & 5.503 & 4.549 & 4.721 & 3.692 & 4.526 & 4.657 & 4.514 & 4.664 & 5.120 \\
\hline
\end{tabular}




\begin{tabular}{|c|c|c|c|c|c|c|c|c|c|c|c|}
\hline & $\mathbf{H}_{\mathbf{O}}$ & 0.600 & 0.888 & 0.722 & 0.055 & 0.609 & 0.687 & 0.562 & 0.600 & 0.536 & 0.640 \\
\hline & $\mathbf{H}_{\mathbf{E}}$ & 0.748 & 0.849 & 0.719 & 0.804 & 0.703 & 0.754 & 0.804 & 0.742 & 0.773 & 0.817 \\
\hline & $\mathbf{P}_{\mathrm{HW}}$ & 0.0620 & 0.1009 & 0.0156 & 0 & 0.5314 & 0.2983 & 0.0429 & 0.4767 & 0.0008 & 0.0027 \\
\hline & $\mathbf{F}_{\text {IS }}$ & 0.202 & -0.048 & -0.005 & 0.933 & 0.137 & 0.091 & 0.308 & 0.196 & 0.311 & 0.22 \\
\hline & PIC & 0.702 & 0.8011 & 0.6611 & 0.7481 & 0.6319 & 0.6898 & 0.7430 & 0.6814 & 0.7218 & 0.7714 \\
\hline \multirow[t]{7}{*}{ Cmacr $\mu 05$} & $\mathbf{N}_{\mathrm{A}}$ & 6 & 4 & 3 & 5 & 6 & 7 & 7 & 8 & 6 & 7 \\
\hline & $\mathbf{A}_{\mathrm{R}}$ & 4.412 & 3.697 & 2.984 & 4.650 & 4.899 & 5.090 & 5.163 & 5.918 & 4.618 & 5.104 \\
\hline & $\mathbf{H}_{\mathbf{O}}$ & 0.542 & 0.666 & 0.666 & 0.277 & 0.9256 & 0.812 & 0.588 & 0.761 & 0.778 & 0.846 \\
\hline & $\mathbf{H}_{\mathrm{E}}$ & 0.753 & 0.727 & 0.671 & 0.798 & 0.807 & 0.790 & 0.784 & 0.851 & 0.762 & 0.797 \\
\hline & $\mathbf{P}_{\mathrm{HW}}$ & 0.0100 & 0.8176 & 1 & 0 & 0.4623 & 0.3674 & 0.0669 & 0.3332 & 0.1373 & 0.5507 \\
\hline & $\mathbf{F}_{\text {IS }}$ & 0.286 & 0.085 & 0.007 & 0.659 & -0.15 & -0.029 & 0.256 & 0.107 & -0.022 & -0.062 \\
\hline & PIC & 0.695 & 0.6505 & 0.5786 & 0.7400 & 0.7598 & 0.7314 & 0.7274 & 0.8092 & 0.7092 & 0.7525 \\
\hline \multirow[t]{7}{*}{ Cmacr $\mu 07$} & $\mathbf{N}_{\mathrm{A}}$ & 11 & 8 & 8 & 9 & 13 & 10 & 9 & 12 & 12 & 10 \\
\hline & $\mathbf{A}_{\mathbf{R}}$ & 6.423 & 6.187 & 6.038 & 5.576 & 8.013 & 7.009 & 6.291 & 6.819 & 6.678 & 6.641 \\
\hline & $\mathbf{H}_{\mathbf{O}}$ & 0.960 & 0.888 & 0.777 & 0.778 & 0.789 & 1.000 & 0.706 & 0.850 & 0.629 & 0.869 \\
\hline & $\mathbf{H}_{\mathbf{E}}$ & 0.860 & 0.860 & 0.836 & 0.797 & 0.920 & 0.895 & 0.869 & 0.863 & 0.879 & 0.867 \\
\hline & $\mathbf{P}_{\mathrm{HW}}$ & 0.0010 & 0.3738 & 0.0035 & 0.1277 & 0.2151 & 0.1873 & 0.1690 & 0.5806 & 0.0014 & 0.4341 \\
\hline & $\mathbf{F}_{\text {IS }}$ & -0.118 & -0.034 & 0.072 & 0.025 & 0.146 & -0.121 & 0.193 & 0.015 & 0.288 & -0.003 \\
\hline & PIC & 0.825 & 0.8166 & 0.7921 & 0.7485 & 0.8873 & 0.8527 & 0.8250 & 0.8255 & 0.8476 & 0.8314 \\
\hline \multirow[t]{7}{*}{ Cmacr $\mu 08$} & $\mathbf{N}_{\mathrm{A}}$ & 5 & 4 & 4 & 4 & 8 & 6 & 6 & 6 & 6 & 6 \\
\hline & $\mathbf{A}_{\mathbf{R}}$ & 4.044 & 3.793 & 3.050 & 3.518 & 5.754 & 4.042 & 5.359 & 4.534 & 4.920 & 3.954 \\
\hline & $\mathbf{H}_{\mathbf{O}}$ & 0.375 & 0.500 & 0.500 & 0.889 & 0.760 & 0.562 & 0.353 & 0.562 & 0.400 & 0.320 \\
\hline & $\mathbf{H}_{\mathbf{E}}$ & 0.747 & 0.686 & 0.613 & 0.694 & 0.815 & 0.695 & 0.830 & 0.767 & 0.813 & 0.651 \\
\hline & $\mathbf{P}_{\mathrm{HW}}$ & 0 & 0.1945 & 0.2582 & 0.0086 & 0.0818 & 0.0756 & 0 & 0.4948 & 0 & 0.0001 \\
\hline & $\mathbf{F}_{\text {IS }}$ & 0.504 & 0.277 & 0.188 & -0.292 & 0.068 & 0.196 & 0.583 & 0.272 & 0.513 & 0.514 \\
\hline & PIC & 0.684 & 0.6204 & 0.5121 & 0.6123 & 0.7759 & 0.6226 & 0.7791 & 0.7001 & 0.7655 & 0.5953 \\
\hline \multirow[t]{7}{*}{ Стасr $\mu 09$} & $\mathbf{N}_{\mathrm{A}}$ & 4 & 4 & 4 & 5 & 5 & 2 & 5 & 5 & 4 & 5 \\
\hline & $\mathbf{A}_{\mathbf{R}}$ & 3.695 & 3.387 & 3.737 & 3.366 & 3.764 & 2.000 & 4.247 & 4.155 & 3.841 & 4.154 \\
\hline & $\mathbf{H}_{\mathbf{O}}$ & 0.783 & 0.600 & 0.833 & 0.687 & 0.800 & 0.667 & 0.706 & 0.727 & 0.667 & 0.571 \\
\hline & $\mathbf{H}_{\mathrm{E}}$ & 0.675 & 0.531 & 0.694 & 0.613 & 0.619 & 0.485 & 0.768 & 0.706 & 0.741 & 0.717 \\
\hline & $\mathbf{P}_{\mathrm{HW}}$ & 0.4980 & 1 & 0.8250 & 0.16747 & 0.3993 & 1 & 0.0776 & 0.9434 & 0.8724 & 0.2979 \\
\hline & $\mathbf{F}_{\text {IS }}$ & -0.163 & -0.135 & -0.209 & -0.126 & -0.301 & -0.429 & 0.084 & -0.032 & 0.103 & 0.207 \\
\hline & PIC & 0.611 & 0.475 & 0.623 & 0.522 & 0.566 & 0.346 & 0.702 & 0.620 & 0.669 & 0.655 \\
\hline \multirow[t]{7}{*}{ Cmacr $\mu 10$} & $\mathbf{N}_{\mathrm{A}}$ & 4 & 5 & 4 & 5 & 4 & 6 & 5 & 8 & 5 & 5 \\
\hline & $\mathbf{A}_{\mathbf{R}}$ & 3.751 & 4.244 & 3.869 & 4.251 & 3.289 & 4.136 & 3.987 & 5.777 & 4.063 & 3.646 \\
\hline & $\mathbf{H}_{\mathbf{O}}$ & 0.857 & 0.818 & 0.588 & 0.417 & 0.682 & 0.625 & 0.600 & 0.722 & 0.577 & 0.458 \\
\hline & $\mathbf{H}_{\mathbf{E}}$ & 0.693 & 0.671 & 0.749 & 0.764 & 0.644 & 0.697 & 0.722 & 0.841 & 0.700 & 0.554 \\
\hline & $\mathbf{P}_{\mathrm{HW}}$ & 0.6370 & 0.3618 & 0.0028 & 0.0109 & 0.7049 & 0.3523 & 0.0546 & 0.8643 & 0.2321 & 0.0348 \\
\hline & $\mathbf{F}_{\text {IS }}$ & -0.244 & -0.233 & 0.22 & 0.466 & -0.061 & 0.107 & 0.174 & 0.145 & 0.179 & 0.176 \\
\hline & PIC & 0.627 & 0.601 & 0.676 & 0.685 & 0.557 & 0.621 & 0.643 & 0.794 & 0.640 & 0.508 \\
\hline \multirow[t]{7}{*}{ Cmacr $\mu 12$} & $\mathbf{N}_{\mathrm{A}}$ & 5 & 5 & 2 & 6 & 9 & 6 & 7 & 7 & 8 & 8 \\
\hline & $\mathbf{A}_{\mathbf{R}}$ & 3.092 & 3.550 & 1.999 & 4.172 & 5.811 & 5.391 & 5.553 & 5.958 & 6.071 & 5.757 \\
\hline & $\mathbf{H}_{\mathbf{O}}$ & 0.240 & 0.333 & 0.000 & 0.222 & 0.500 & 0.461 & 0.294 & 0.450 & 0.464 & 0.680 \\
\hline & $\mathbf{H}_{\mathbf{E}}$ & 0.601 & 0.654 & 0.476 & 0.701 & 0.792 & 0.837 & 0.829 & 0.860 & 0.860 & 0.808 \\
\hline & $\mathbf{P}_{\mathrm{HW}}$ & 0 & 0.0026 & 0.0001 & 0 & 0.0001 & 0.0314 & 0 & 0.0007 & 0 & 0.0348 \\
\hline & $\mathbf{F}_{\text {IS }}$ & 0.606 & 0.498 & 1 & 0.689 & 0.374 & 0.459 & 0.652 & 0.483 & 0.465 & 0.161 \\
\hline & PIC & 0.505 & 0.575 & 0.354 & 0.628 & 0.759 & 0.776 & 0.778 & 0.818 & 0.825 & 0.770 \\
\hline \multirow[t]{3}{*}{ Cmacr $\mu 13$} & $\mathbf{N}_{\mathbf{A}}$ & 5 & 3 & 5 & 4 & 8 & 5 & 6 & 7 & 5 & 6 \\
\hline & $\mathbf{A}_{\mathbf{R}}$ & 3.508 & 2.333 & 4.156 & 3.152 & 4.921 & 3.592 & 3.883 & 5.263 & 3.451 & 4.719 \\
\hline & $\mathbf{H}_{\mathbf{O}}$ & 0.680 & 0.500 & 0.667 & 0.777 & 0.556 & 0.600 & 0.470 & 0.667 & 0.571 & 0.640 \\
\hline
\end{tabular}




\begin{tabular}{llllllllllll}
\hline & $\mathbf{H}_{\text {E }}$ & 0.555 & 0.522 & 0.655 & 0.624 & 0.750 & 0.616 & 0.634 & 0.813 & 0.644 & 0.760 \\
& $\mathbf{P}_{\text {HW }}$ & 0.3876 & 1 & 0.8020 & 0.0260 & 0.0099 & 0.2125 & 0.2027 & 0.0509 & 0.5318 & 0.0642 \\
& F $_{\text {IS }}$ & -0.231 & 0.044 & -0.017 & -0.256 & 0.263 & 0.027 & 0.264 & 0.184 & 0.115 & 0.161 \\
& PIC & 0.505 & 0.404 & 0.602 & 0.531 & 0.701 & 0.540 & 0.569 & 0.764 & 0.564 & 0.709 \\
\hline Average (se1) & $\mathbf{N}_{\mathbf{A}}$ & $\mathbf{6 . 1}$ & $\mathbf{4 . 8}$ & $\mathbf{4 . 5}$ & $\mathbf{5 . 1}$ & $\mathbf{6 . 7}$ & $\mathbf{5 . 8}$ & $\mathbf{6 . 1}$ & $\mathbf{7 . 1}$ & $\mathbf{6 . 4}$ & $\mathbf{6 . 4}$ \\
& $\mathbf{A}_{\mathbf{R}}$ & $\mathbf{4 . 1 9 8}$ & $\mathbf{3 . 9 9 7}$ & $\mathbf{3 . 7 0 1}$ & $\mathbf{3 . 9 5 0}$ & $\mathbf{4 . 6 0 9}$ & $\mathbf{4 . 3 2 7}$ & $\mathbf{4 . 7 0 4}$ & $\mathbf{5 . 1 2 9}$ & $\mathbf{4 . 6 1 2}$ & $\mathbf{4 . 7 1 1}$ \\
& H $_{\mathbf{O}}$ & $\mathbf{0 . 6 4 0}$ & $\mathbf{0 . 6 4 1}$ & $\mathbf{0 . 6 2 5}$ & $\mathbf{0 . 4 4 4}$ & $\mathbf{0 . 6 4 3}$ & $\mathbf{0 . 6 7 2}$ & $\mathbf{0 . 5 3 4}$ & $\mathbf{0 . 6 6 9}$ & $\mathbf{0 . 6 0 1}$ & $\mathbf{0 . 6 2 4}$ \\
& H $_{\text {E }}$ & $\mathbf{0 . 7 0 0}$ & $\mathbf{0 . 6 6 9}$ & $\mathbf{0 . 6 6 3}$ & $\mathbf{0 . 6 7 8}$ & $\mathbf{0 . 6 9 1}$ & $\mathbf{0 . 7 0 9}$ & $\mathbf{0 . 7 4 4}$ & $\mathbf{0 . 7 8 7}$ & $\mathbf{0 . 7 5 2}$ & $\mathbf{0 . 7 3 7}$ \\
& F $_{\text {IS }}$ & $\mathbf{0 . 0 7 9}$ & $\mathbf{0 . 0 4 0}$ & $\mathbf{0 . 0 7 1}$ & $\mathbf{0 . 3 2 7}$ & $\mathbf{0 . 0 4 9}$ & $\mathbf{0 . 0 3 2}$ & $\mathbf{0 . 2 7 4}$ & $\mathbf{0 . 1 4 7}$ & $\mathbf{0 . 1 8 9}$ & $\mathbf{0 . 1 6 5}$ \\
\hline
\end{tabular}

Note. BRA = Bragança, $\mathrm{CAP}=$ Capanema, $\mathrm{PB}=$ Peixe Boi, TRA $=$ Tracuateua, $\mathrm{CDA}=$ Conceição do Araguaia, $\mathrm{STM}=$ Santarém, ITB $=$ Itaituba, MTA $=$ Monte Alegre, $\mathrm{OB}=$ Óbidos, ORX $=$ Oriximiná. $*$ Marker not in Hardy-Weinberg equilibrium $(\mathrm{P}<0.005)$.

Appendix 2. $\mathrm{D}_{\mathrm{EST}}$ (below the diagonal) and $\mathrm{R}_{\mathrm{ST}}$ (above the diagonal) values for the farmed tambaqui analyzed in the present study, based on 10 microsatellite loci

\begin{tabular}{|c|c|c|c|c|c|c|c|c|c|c|}
\hline Fish Farm & $\begin{array}{l}\text { BRA } \\
(n=25)\end{array}$ & $\begin{array}{l}\text { CAP } \\
(n=18)\end{array}$ & $\begin{array}{l}\text { PB } \\
(n=18)\end{array}$ & $\begin{array}{l}\text { TRA } \\
(n=18)\end{array}$ & $\begin{array}{l}\text { STM } \\
(n=16)\end{array}$ & $\begin{array}{l}\text { ITB } \\
(n=18)\end{array}$ & $\begin{array}{l}\text { MTA } \\
(n=21)\end{array}$ & $\begin{array}{l}\text { OB } \\
(n=28)\end{array}$ & $\begin{array}{l}\text { ORX } \\
(n=26)\end{array}$ & $\begin{array}{l}\text { CDA } \\
(n=28)\end{array}$ \\
\hline BRA & - & -0.014 & -0.02 & 0.079 & 0.036 & 0.115 & 0.096 & 0.01 & 0.114 & 0.033 \\
\hline CAP & 0.034 & - & -0.023 & 0.077 & 0.033 & 0.094 & 0.071 & -0.003 & 0.086 & 0.027 \\
\hline PB & 0.029 & 0.115 & - & 0.09 & 0.053 & 0.101 & 0.099 & 0.006 & 0.122 & 0.007 \\
\hline TRA & 0.180 & 0.205 & 0.219 & - & 0.062 & 0.067 & 0.171 & 0.109 & 0.174 & 0.109 \\
\hline STM & 0.253 & 0.235 & 0.310 & 0.288 & - & 0.053 & 0.064 & 0.02 & 0.05 & 0.058 \\
\hline ITB & 0.164 & 0.217 & 0.243 & 0.217 & 0.152 & - & -0.008 & 0.09 & 0.093 & 0.005 \\
\hline MTA & 0.189 & 0.240 & 0.271 & 0.331 & 0.177 & 0.078 & - & 0.058 & 0.1 & 0.094 \\
\hline OB & 0.172 & 0.247 & 0.218 & 0.303 & 0.141 & 0.049 & 0.149 & - & 0.054 & 0.045 \\
\hline ORX & 0.271 & 0.311 & 0.319 & 0.370 & 0.254 & 0.049 & 0.047 & 0.187 & - & 0.121 \\
\hline CDA & 0.118 & 0.145 & 0.214 & 0.230 & 0.217 & 0.165 & 0.234 & 0.233 & 0.311 & - \\
\hline
\end{tabular}

Note. BRA = Bragança, CAP = Capanema, $\mathrm{PB}=$ Peixe Boi, TRA = Tracuateua, $\mathrm{CDA}=$ Conceição do Araguaia, $\mathrm{STM}=$ Santarém, ITB $=$ Itaituba, MTA $=$ Monte Alegre, $\mathrm{OB}=$ Óbidos, $\mathrm{ORX}=$ Oriximiná. $*$ Bold type indicates significant values after the Bonferroni correction (adjusted p-value $<0.005$ ).

\section{Copyrights}

Copyright for this article is retained by the author(s), with first publication rights granted to the journal.

This is an open-access article distributed under the terms and conditions of the Creative Commons Attribution license (http://creativecommons.org/licenses/by/4.0/). 